\title{
Feasibility Analysis of Chinese NGOs Participating in Preschool Education
}

\author{
Feng Zou \\ College of Politics and Public Administration, Guangxi Normal University, Guilin, China \\ Email: 1442783275@qq.com
}

How to cite this paper: Zou, F. (2019) Feasibility Analysis of Chinese NGOs Participating in Preschool Education. Open Journal of Social Sciences, 7, 367-374. https://doi.org/10.4236/jss.2019.710031

Received: October 17, 2019

Accepted: October 27, 2019

Published: October 30, 2019

\begin{abstract}
In China, the participation of NGOs in preschool education stems from government failures and market failures. Preschool education provided by government and private enterprises faces many dilemmas. In terms of value orientation, NGOs agree with preschool education. NGOs can participate in preschool education as the main body of supervision and propaganda, the main body of social education, the main body of education value maintenance and preschool education institution provider. At present, there are many difficulties in the participation of NGOs in preschool education, and corresponding measures need to be taken.
\end{abstract}

\section{Keywords}

NGOs, Preschool Education, Feasibility

\section{Introduction}

In recent years, the frequent occurrence of child abuse incidents in preschool education in China has triggered great concern. Preschool education is a special field of education, how to make preschool education develop healthily and let children grow up happily are becoming hot topics for Chinese parents and scholars. The research of NGOs abroad has been relatively perfect, but the research in China has to be deepened. Foreign researches on NGOs mainly focus on the role of NGOs in various fields. Accounting and accountability practices differ according to the type of NGOs. We urge the future researchers to pay attention to a number of areas of NGO accountability and governance by taking a more critical perspective on it [1]. Financial incentives and resources committed by NGOs can foster collaborative relationships with journalists, thus increasing promotional and advocacy-based reporting [2]. From an urban governance 
perspective, the prominent role of NGOs increases accountability of the public programs in certain limited capacities [3]. In addition, there are some researches about the reputation of NGOs. Organizations enjoy higher reputations for organizational effectiveness. Reputations are critical to the construction of NGO authority and to patterns of collaboration [4]. The tendency to focus on short-term goals that may in the long run hurt the investment reputation of the countries and NGOs themselves [5]. This paper argues that China can learn from the experience of western NGOs in social life. Promoting the participation of NGOs in preschool education and keeping the good reputation of NGOs can prevent the occurrence of child abuse incidents.

NGOs are also called NPOs, voluntary organizations, and the third sector in a broad sense. There is no unified definition of NGOs at home and abroad. Such organizations are often defined as organized, non-profit, self-governing and voluntary. In addition, preschool education refers to the education of children from the fetus to the primary school stage. Preschool education must adhere to the principle of protection and education, the principle of caring, and the principle of skill. In the current social context, NGOs appear in various fields of China, and can also enter the people's vision as an important preschool education participant.

\section{Relationship between NGOs and Preschool Education}

\subsection{Participation of NGOs in Preschool Education}

Generally, in China, there are mainly three types of providing preschool education, public preschool education (education provided by government), private preschool education (education provided by market subjects) and preschool education provided by NGOs. NGOs have emerged to compensate for government failures and market failures in terms of the former two ways of providing education. As far as public preschool education is concerned, due to the policy inclination and institutional reasons, many advantageous resources are concentrated in public preschool education. In China, with the liberalization of the national second-child policy and the public's emphasis on preschool education, the demand for preschool education is on the rise. For most families, public schools are still the first choice of many parents, but the number of public preschool education schools is limited, and the teaching staff has been in a relatively tight state now. That is to say, public preschools are in short supply. The contradiction between the supply and the demand of the public for preschool education emerges. On the other hand, private preschool education is a way to supplement education in the face of the failure of public preschool education. However, due to the excessive market-oriented development of private education, especially education industrialization, private preschool education has emphasized economic interests instead of public welfare, it only pursues economic interests, and neglects its social responsibilities. The high cost of private preschool education will not only bring a large economic burden on parents, but also dis- 
torts the initial purpose of public welfare and fairness. In addition, due to the lack of supervision, public preschool education and private preschool education face behavior anomie. When public preschool education and private preschool education are in trouble, NGOs directly or indirectly participating in preschool education has become another important way to make preschool education better.

\subsection{Value Orientation}

Preschool education advocates dedication and caring for children. The educational objects faced by preschool education are children. Due to their physical and psychological specificity, preschool children are immature in mind and body, and their defense abilities are relatively low. Therefore, teachers who are engaged in preschool education are required to impart some knowledge as well as the intelligent inspiration, and basic skills to children. More importantly, because children are in the initial stage of physical development, teacher's protection of their bodies is also emphasized. In addition, education is now increasingly emphasizing public welfare, and preschool education generally should benefit all age-appropriate children so that they can enjoy equal education at the starting line. As a section of the service industry, preschool education requires preschool teachers to be responsible and caring for children. All of the above aspects require that preschool education needs to be centered on preschool children and promote the dedication and caring spirit of preschool teachers. On the other hand, NGOs are different from government organizations and enterprise organizations, they do not aim at pursuing economic interests, but are committed to expressing citizens' will, pursuing social fairness and justice, and advocating social care, voluntary spirit, and dedication. To sum up, NGOs and preschool education have great fits in values.

\section{Why Are NGOs Necessary in Preschool Education}

\subsection{To Remedy Government Failures and Market Failures in Preschool Education}

As the main provider of public preschool education, the government regards fairness as value orientation. The government can promote the development of education towards the direction of public welfare and equalization, but it will face problems such as inefficiency and financial pressure in the allocation of educational resources. As another main provider of private preschool education, the market can satisfy the people's demand for the diversification and individualization of preschool education. In comparison, the efficiency of providing preschool education of market is higher than that of the government. However, the pursuit of economic interests will cause problems such as unfair education and other issues, thus enlarging education gap. The participation of NGOs in preschool education can make up for the failures of the government and the market. On one hand, it emphasizes the fairness of education through volunteer service, 
and on the other hand, it guarantees its sustainable development through government purchasing service or social donation, thus taking into account efficiency and fairness. Table 1 shows the value, advantage and disadvantage of government, market, NGOs in providing preschool education.

\subsection{To Solve the Contradiction between the Increase in Demand for Preschool Education and the Insufficient Supply}

As explained above, an important issue in preschool education is the contradiction between the increase in demand for preschool education and the insufficient supply. As a major provider of preschool education, NGOs can solve the contradiction. Parents can have more choices through preschool institutions founded by NGOs. By matching their own conditions, they can find a school that is suitable for their children and suitable for their family's economic conditions. Relatively speaking, NGOs build up preschool institutions that are not as expensive as private preschool education, at the same time, they can meet the fairness of education and therefore preschools founded by NGOs can become the choice of many parents.

\subsection{To Supervise Preschool Education and Provide Preschool Education Services}

As far as the important supervisory body is concerned, the social supervision or external supervision of preschool education can be transformed into a 360-degree supervision network, that is, citizen supervision, social group supervision, and public opinion supervision (Figure 1). We are familiar with citizen

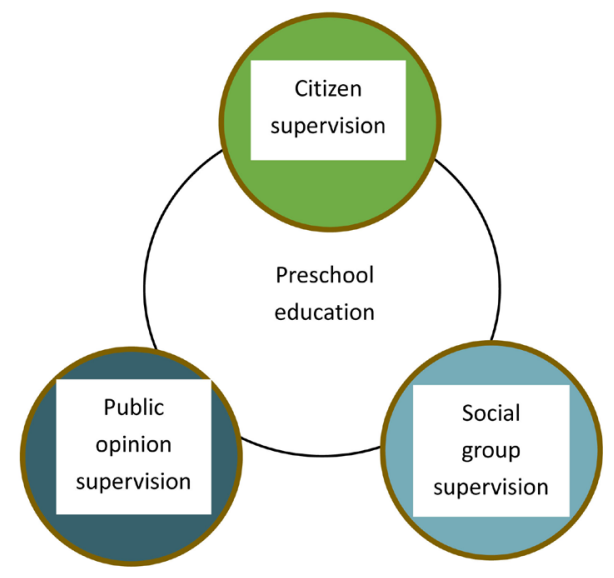

Figure 1. Three supervisory ways in preschool education.

Table 1. Subject, value, advantage and disadvantage in providing preschool education.

\begin{tabular}{cccc}
\hline Subject & Value & Advantage & Disadvantage \\
\hline Government & Justice & Satisfying the equalization of demand & Financial pressure \\
Market & Efficiency & Satisfying the diversity of needs & Education gap \\
NGO & Public interest & Volunteer service & Lacking of autonomy \\
\hline
\end{tabular}


supervision and public opinion supervision, but the supervision of social groups is less talked about. As an important part of social groups, NGOs in the supervision of preschool education have been ignored. In fact, NGOs are indispensable supervisors of preschool education, they can supervise preschool education and reflect problems in preschool education. In addition, NGOs are important providers of social services for preschool education. The government's main responsibility is to develop some policies and regulations through bureaucracy, provide public goods, and conduct social management, such as performing some infrastructure construction for preschool education. Enterprises provide private products through market mechanisms, such as providing some customized services in preschool education. NGOs provide public welfare products or services through voluntary mechanisms. These three are symbiotic and complementary.

\section{Roles of NGOs in Preschool Education}

\subsection{Supervising Preschool Education and Popularizing Children's Rights and Knowledge as a Supervisory and Propaganda Subject}

NGOs can fully mobilize internal personnel to regularly or irregularly go to kindergartens to supervise the behavior of preschool education subjects, and expose incidents such as child abuse that affect children's physical and mental health in preschool education. On the other hand, as an important propaganda body, NGOs can raise awareness of children's rights protection by convening community publicity meetings, hosting community public welfare lectures, establishing community publicity columns, and distributing leaflets to popularize knowledge on how to protect children's rights and interests.

\subsection{Providing Training to Improve Preschool Teachers' Professional Knowledge and Skills as a Main Body of Social Education}

Public welfare education organizations and personnel in NGOs can hold preschool education lectures, invite preschool education experts and take other measures to train preschool teachers in professional knowledge and education skills, improving the professional level of preschool teachers and the ability to deal with related issues. Preschool teachers are supposed to have relevant professional knowledge, NGOs can act as an intermediary or a direct provider to provide relevant counseling and skills improvement to teachers.

\subsection{Providing Psychological Counseling and Professional Ethics Training for Preschool Teachers as a Main Body of Education Value Maintenance}

Preschool education requires the preschool teachers to have good psychological qualities and moral qualities because of the particularity of the educational objects and the occupation. As a defender of educational value, NGOs, through advocating social care and dedication, use their social resources to guide pre- 
school teachers in encountering psychological dilemmas and psychological barriers when engaging in child care work, and through professional ethics training, NGOs can help preschool teachers improve the sense of identity in preschool education.

\subsection{Establishing Preschool Educational Institutions as a Provider of Quasi-Public Goods}

NGOs are important providers of quasi-public goods. Preschool educational institutions as non-monopoly quasi-public goods can be provided through NGOs. At present, especially in mainland China, there are many private educational institutions and public preschool educational institutions, but very few preschool educational institutions established by NGOs (Table 2). Therefore, NGOs have great room for development in this area.

\section{Discussion and Conclusion}

At present, the scope of NGOs participating in preschool education is not extensive, and there are several reasons. First, the role of NGOs in the supervision and propaganda of preschool education has not attracted enough attention from society. Regarding the main body of supervision, the previous elaboration is more about citizen supervision, legal supervision and public opinion supervision, while social group supervision is often ignored. As important social groups, NGOs have not received enough attention in propaganda. People tend to take the government as the main propaganda subject through television, newspapers, and radio. The propaganda role of NGOs has not attracted people's attention.

Second, because of the shortage of funds, NGOs face a lot of operational difficulties, and limited social service functions such as providing preschool teacher skills training. NGOs have relatively simple sources of funds, mainly membership fees, social donations, and government subsidies. These are far from enough to support the full operation of NGOs. Due to the shortage of funds, the related operations and functions are affected.

Third, because of the NGO scandals, the public question the social responsibility and reputation of NGOs. As far as NGOs are concerned, the public welfare scandals that emerged in recent years have greatly affected the reputation of NGOs. Some NGOs are financially opaque and their funds are unclear. NGOs are used as tools for collecting money. Managers in NGOs take public donations to benefit themselves. The public therefore question the reputation and social

Table 2. Number of private and public preschool institutions from 2013 to 2017 (unit: thousand).

\begin{tabular}{cccccc}
\hline Type & 2013 & 2014 & 2015 & 2016 & 2017 \\
\hline Private preschool institutions & 133.5 & 139.3 & 146.4 & 154.2 & 160.4 \\
Public preschool institutions & 65.1 & 70.6 & 77.3 & 85.6 & 94.6 \\
Total & 198.6 & 209.9 & 223.7 & 239.8 & 255 \\
\hline
\end{tabular}


responsibility of NGOs.

Fourth, due to the excessive regulation conducted by government, NGOs have established few preschool institutions. The government and NGOs are supposed to be cooperative partners, they should work together to provide some services of the society. However, the government now treats NGOs as dissident forces, resulting in NGOs' lacking of independence. NGOs are not able to establish more preschool institutions.

To better play the role of NGOs as the main body of supervision and propaganda in preschool education, increasing publicity and more emphasis on NGOs are addressed. Through publicity of NGOs' values, operating models, etc., we can help the public get a better understanding of NGOs and draw public attention to NGOs. Second, more financial support from the government for NGOs in preschool education is required to enhance the ability of NGOs in providing teachers' professional ethics and psychology training. Third, we must strengthen the self-restraint and self-improvement of NGOs, deepen the members' recognition of the values, thus deepening the public's value recognition of NGOs. Fourth, reshaping the partnership between the government and the NGOs needs to be taken into account. NGOs can alleviate the government's pressure on providing social services, so the government should increase the support for non-profit kindergartens, reduce the economic burden of NGOs by providing subsidies and reducing rents to foster the development of NGOs in preschool areas. Only from these aspects can NGOs play a better role in preschool education.

\section{Acknowledgements}

This research is supported by the Innovation Project of Guangxi Graduate Education (Grant No. YCSW2019077).

\section{Conflicts of Interest}

The author declares no conflicts of interest regarding the publication of this paper.

\section{References}

[1] Cordery, C., Belal, A.R. and Thomson, I. (2019) NGO Accounting and Accountability: Past, Present and Future. Accounting Forum, 43, 1-15. https://doi.org/10.1080/01559982.2019.1593577

[2] Kothari, A. (2018) NGOs and Health Reporting in Tanzania. African Journalism Studies, 39, 42-60. https://doi.org/10.1080/23743670.2018.1473267

[3] Foo, K. (2018) Examining the Role of NGOs in Urban Environmental Governance. Cities, 77, 67-72. https://doi.org/10.1016/j.cities.2018.01.002

[4] Mitchell, G.E. and Stroup, S.S. (2017) The Reputations of NGOs: Peer Evaluations of Effectiveness. The Review of International Organization, 12, 397-419. https://link.springer.com/article/10.1007\%2Fs11558-016-9259-7 https://doi.org/10.1007/s11558-016-9259-7 
[5] Argenti, P.A. and Saghabalyan, A. (2017) Reputation at Risk: The Social Responsibility of NGOs. Corporate Reputation Review, 20, 1-26.

https://doi.org/10.1057/s41299-017-0013-8

https://link.springer.com/article/10.1057\%2Fs41299-017-0013-8 